\title{
Advancing indigenous fruits consumption to promote self-management in ill-health: a critical narrative review
}

\author{
Patricia Tonbra Osunu ${ }^{1}$, Ezekiel Uba Nwose ${ }^{2}$
}

\author{
${ }^{1}$ Department of Public and Community Health, Novena University, Ogume, Delta State, Nigeria \\ ${ }^{2}$ School of Community Health, Charles Sturt University, Orange NSW, Australia
}

Received: 29 March 2021

Accepted: 29 April 2021

\author{
*Correspondence: \\ Dr. Ezekiel Uba Nwose, \\ Email: enwose@csu.edu.au
}

Copyright: $@$ the author(s), publisher and licensee Medip Academy. This is an open-access article distributed under the terms of the Creative Commons Attribution Non-Commercial License, which permits unrestricted non-commercial use, distribution, and reproduction in any medium, provided the original work is properly cited.

\begin{abstract}
Most African communities consume various edible fruits, which are important to their well-being. Some of these edible fruits are indigenous and were well-known to the rural communities. These indigenous fruits can be collected from the wild or planted in home gardens and also as intercrops with staple crops. Some indigenous fruits, wild collection is still practiced, especially in parts of eastern, western and southern Africa. However, some fruits are still imported. A casual verbal survey indicated that many people in the general population do not know that actual differences in nutritional values between these fruits. Therefore, this study was a critical review of some fruits using the USDA database. Results show, for instance, that guava has over $250 \%$ vitamin $\mathrm{C}$ relative to orange. Avocado yields more calories than banana and this is very likely due to the fat/fibre ratio difference. Further, the imported cucumber and watermelon do not seem to have any advantage over the indigenous products. It concluded that the hidden potential of these indigenous fruits needs to be advanced and exploited to improve their consumption as they play a pivotal role in health economics of healthy dietary habit and self-management of ill-health.
\end{abstract}

Keywords: Nutrition values, Nigerian indigenous fruits, Medicinal uses

\section{INTRODUCTION}

Plenty of African farmers grow commercially popular fruits that have become indigenous to the region. This includes avocadoes (Persea americana), oranges (Citrus sinensis), lime (Citrus aurantifoila), Lemon (Citrus limon), guava (Psidium guajava), cucumber (Cucumis sativus), banana (Musa acuminata), pawpaw (Papaya), coconut (Cocos nucifera), apple (Malus domestica), pineapple (Anas comosus), mango (Mangifera indica), carrot (Daucus carota sub spp. sativus), and watermelon (Citrullus lanatus) amongst others.

However, there are over eight hundred fruit species, but what would be found in many local community markets is three or four. This is partly because relatively few farmers intentionally grow indigenous fruits. In the past decade, disparity between natural varieties and market representations existed for indigenous fruity vegetables. ${ }^{1}$ Although, many fruits have been promoted hence making resurgence into the international market, the role of indigenous fruits in various local cultures have yet to be fully appreciated..$^{2-4}$

It has been documented that missionaries complicated things by their lack of knowledge and/or prejudiced view regarding the socio-cultural values of fruits such as aphrodisiac effects. It is said that the missionaries believed hence considered such usage to be immoral. Other notable usage considered that formed basis of condemnation was brewing alcoholic beverages. ${ }^{1}$ Therefore, that facts that aphrodisiac effect was probably enhancing sexual health or limiting impotence; or that consumption of beverages is 
a dietary option of taking the digestive values of fruits were abused. ${ }^{5}$

Nevertheless, what all indigenous fruit crops seem to have in common is lack of intentional farming. It is known that there have been little incentive to intentionally cultivate indigenous fruits at commercial cropping level, and the attributed reasons is the length of time it takes to mature. ${ }^{1}$ What is yet to be exhaustively addressed includes the different medicinal values of available fruits that could inform food choices and improved consumption, which will affect demands an route farmers' incentive to increase production.

\section{OBJECTIVE AND METHODS}

For the purpose of this review, a critical narrative method was adopted. Ten fruits commonly found in Nigeria market were discretionally selected. The objective is to articulate their medicinal values with a view to advance their consumption for health promotion. The nutritional database of US Department of agriculture was used. Two sets of comparisons are made including (1) lemon, lime and orange-re: considering general knowledge about their citric acid content; and (2) avocado, banana, cucumber, guava, pineapple and watermelon-re: considering that cucumber and watermelon are rarely grown in the southern part of Nigeria.

\section{AVOCADO PEAR (PERSEA AMERICANA)}

\section{Overview}

Knowledge of this fruit dates back to the $8^{\text {th }}$ century BC. It has been used for the treatment of scabies in traditional medicine. ${ }^{6}$ The avocado pear common in Nigeria is a fruit with single seed. The avocado is assumed to have originated from Central America. ${ }^{7}$ However, in terms of cultivation, the fruit tree is known to be self-pollinating. It is rarely farmed in Nigeria. Instead, individuals grow it as domestic fruit trees.

\section{Nutritional values}

Avocado is rich in essential and non-essential fatty acids as well as minerals. ${ }^{8}$ Notable vitamins' content of avocados include A, B-complex, C, E, and $\mathrm{K}$ as well as copper and magnesium, amongst others. Avocado pear is a great source of antioxidants, especially including vitamins $\mathrm{E}$ and $\mathrm{C}$. This fruit food is a very digestible including its fats content. It has a fat content of about $88 \%$ of the total calories, and this is nearly 20 times the average for some other fruits. ${ }^{6}$ A typical 200 gm avocado may contain as much as $30 \mathrm{gm}$ of fat, out of which $67 \%$ are monounsaturated fats i.e. health promoting. ${ }^{8}$

\section{Traditional uses of avocado}

Avocado oil are used for various types of traditional medicine practices such as cosmetics and facial treatment, as well as weight management program. ${ }^{6}$ It is also used for the treatment of various health conditions including diabetes and hypertension amongst others. These uses are based on its antioxidant, minerals and vitamin potentials. ${ }^{7}$ The avocado seed is always either thrown away or planted on rare occasion. Yet, a piece of emerging knowledge is that the seed is equally rich in nutrients and good enough for medicinal use. ${ }^{9}$ Hence there is more to fruit to be appropriated in medical nutrition therapy

Table 1: Avocado fruit composition. ${ }^{8}$

\begin{tabular}{|c|c|c|}
\hline Variables & Nutrient & Quantity \\
\hline \multirow{6}{*}{$\begin{array}{l}\text { Proximate } \\
\text { content }\end{array}$} & Water $(\%)$ & 72 \\
\hline & Lipids (\%) & 18 \\
\hline & Carbohydrate (\%) & 5.6 \\
\hline & Protein $(\%)$ & 1.8 \\
\hline & Fibre $(\%)$ & 1.4 \\
\hline & Ash (\%) & 1.2 \\
\hline \multirow{8}{*}{$\begin{array}{l}\text { Vitamins (mg } \\
\left.100 \mathrm{~g}^{-1}\right)\end{array}$} & Ascorbic acid & 11.0 \\
\hline & Thiamine & 0.07 \\
\hline & Riboflavin & 0.12 \\
\hline & Nicotin acid & 1.9 \\
\hline & Vitamin B6 & 0.62 \\
\hline & Folic acid & 0.04 \\
\hline & A-Carotenoids & 0.29 \\
\hline & B-Carotenoids & 0.03 \\
\hline
\end{tabular}

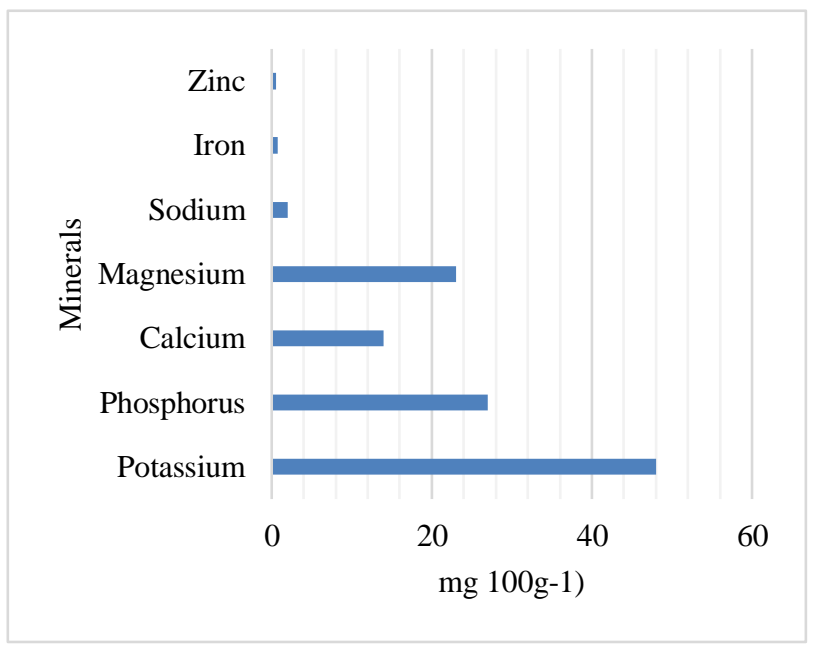

Figure 1: Mineral content of avocado pear. ${ }^{8}$

\section{SWEET ORANGES (CITRUS SINESIS)}

\section{Overview}

Various species of citrus are in existence and includes citrus limon (lemon), citrus aurantium (sour orange), citrus paradisi (grapefruit), citrus reticulata (mandarin, tangerine), and citrus sinensis (sweet orange) amongst others. ${ }^{10}$ Therefore, it pertinent to note the specie being discussed here i.e. sweet orange. In Nigeria, production is 
sweet orange quite common relative to other fruit trees. Many landlords plant it as domestic fruit tree. Thus, it is very common to find oranges in virtually every local market. Also, there are many cultivars i.e., varieties of sweet orange that have been adopted. Associated with this adoption is plant disease problems. The origin of this probably most important fruit tree in the world is unclear. Although there is indication of annual production volume estimated to be over 122 million tonnes. ${ }^{11}$ Other literature indicate much less around 53 million tonnes. ${ }^{12}$ Further, there is indication of global fluctuation versus steady increase in Nigeria (Table 2).

Table 2: Global vs. Nigeria's production of orange (million tonnes).

\begin{tabular}{|lll|}
\hline Year & Nigeria $^{\mathbf{1 3}}$ & Global $^{\mathbf{1 2}}$ \\
\hline $\mathbf{2 0 1 8}$ & 4.07 & 48.23 \\
\hline $\mathbf{2 0 1 7}$ & 4.02 & 53.81 \\
\hline $\mathbf{2 0 1 6}$ & 3.98 & 47.06 \\
\hline $\mathbf{2 0 1 5}$ & 3.96 & 48.94 \\
\hline $\mathbf{2 0 1 4}$ & 3.78 & 52.08 \\
\hline $\mathbf{2 0 1 3}$ & 3.8 & 49.85 \\
\hline
\end{tabular}

\section{Nutritional value}

Oranges are known for their vitamin C content, and this is a very powerful antioxidant that helps protect cells from damage normal stress of life. It is estimated that vitamin C constitutes $64 \%$ of total vitamins in the fruit, hence a medium orange is further indicated to be able to provide the daily dietary requirement of vitamin $\mathrm{C}$ for adults (Figure 2). Orange also contains significant amounts of health-promoting compounds such as flavanones. Besides vitamins, orange is a good source of fibre and minerals, especially calcium and potassium as a result of the high amount of both soluble and insoluble fibre in orange is helpful for control higher cholesterol and major lipid problem of the human body. ${ }^{14}$

\section{Traditional and complementary medicine uses}

The phytochemicals in orange help support the body and protect from several ill-health conditions such as cancer, cardiovascular diseases, and diabetes. In particular, the antioxidant and flavonoid properties are utilized in modulation of immune system and inflammation in cases of infection and stress (anxiety, depressant, or pain). ${ }^{15}$

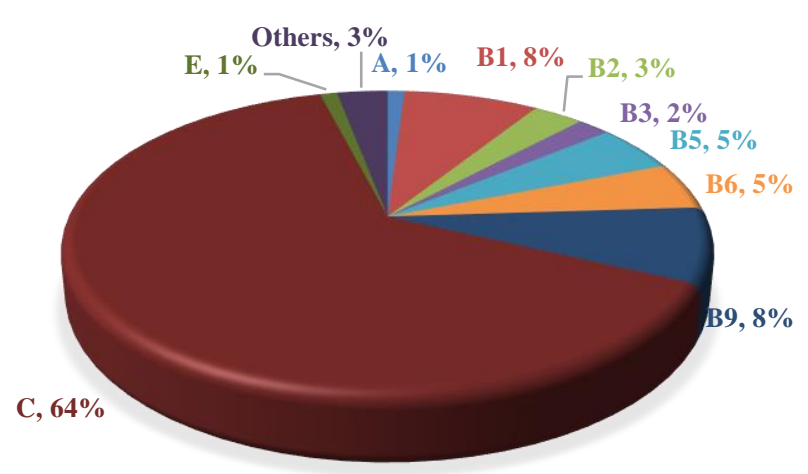

Figure 2: Vitamins composition of sweet orange excerpted from USDA 2014. ${ }^{11}$

\section{LIME (CITRUS AURANTIFOILA)}

\section{Overview}

Lime is in the same citrus family, but unlike orange, not sweet. The fruit has same anatomical structures of citruses including the juice sacs that are yellowish pulp vesicles and seeds. ${ }^{16}$ Lime probably originated from the South East Asia, but it is currently cultivated all over the world. In Nigeria, lime is more produced in the middle-belt, midwest and western regions. ${ }^{17}$

\section{Nutritional value}

Lime contains active phytochemical substances similar to sweet orange. Hence, it is equally useful as antioxidant, anti-cancer and antibiotic, amongst others. ${ }^{18}$ In addition to their unique phytonutrients properties, limes are an excellent source of vitamin $\mathrm{C}$, one of the most important antioxidants in nature. Vitamin $\mathrm{C}$ is one of the main antioxidants found in food and the primary water-soluble antioxidant in the body. ${ }^{16}$

\section{Traditional uses}

In cholera epidemics, the use of lime juice inclusion as part of the main meal was part of treatment regimen. Fascinating research study reports on the healing properties of lime have speculated possible effect on cell cycle including death and death. ${ }^{16,18}$ These are additional to effects similar to those of orange.

Table 3: Comparison of proximate contents of lemon, lime and orange.

\begin{tabular}{|llllllll|}
\hline NDB (no.) & $\mathbf{0 9 1 5 0}$ & $\mathbf{0 9 1 5 2}$ & $\mathbf{0 9 1 5 9}$ & $\mathbf{0 9 1 6 0}$ & $\mathbf{0 9 2 0 5}$ & $\mathbf{0 9 2 0 6}$ \\
\hline \multirow{2}{*}{ Fruits } & Lemon & & Lime & & \multicolumn{2}{c|}{ Orange } \\
\cline { 2 - 7 } & Raw & Juice & Raw & Juice & Raw & Juice \\
\hline Water (gm) & 88.98 & 92.31 & 88.26 & 90.79 & 82.3 & 88.3 \\
\hline Energy (Kcal) & 29 & 22 & 30 & 25 & 63 & 45 \\
\hline Protein (gm) & 1.1 & 0.35 & 0.7 & 0.42 & 1.3 & 0.7 \\
\hline Lipid (gm) & 0.3 & 0.24 & 0.2 & 0.07 & 0.3 & 0.2 \\
\hline
\end{tabular}




\begin{tabular}{|lllllll|}
\hline NDB (no.) & $\mathbf{0 9 1 5 0}$ & $\mathbf{0 9 1 5 2}$ & $\mathbf{0 9 1 5 9}$ & $\mathbf{0 9 1 6 0}$ & $\mathbf{0 9 2 0 5}$ & $\mathbf{0 9 2 0 6}$ \\
\hline Ash $(\mathbf{g m})$ & 0.3 & 0.21 & 0.3 & 0.31 & 0.6 & 0.4 \\
\hline Carbohydrate $(\mathbf{g m})$ & 9.32 & 6.9 & 10.54 & 8.42 & 15.5 & 10.4 \\
\hline Fiber $(\mathbf{g m})$ & 2.8 & 0.3 & 2.8 & 0.4 & 4.5 & 0.2 \\
\hline Sugar $(\mathbf{g m})$ & 2.5 & 2.52 & 1.69 & 1.69 & & 8.4 \\
\hline
\end{tabular}

\section{LEMON (CITRUS LIMON)}

\section{Overview}

Lemon (Citrus limon (L.) Burm.) is an important medicinal plant of the Rutaceae family, that originated in tropical and subtropical Southeast Asia. In Nigeria, it is cultivated and consumed as alternative to other citrus fruits, especially the common lemon and sweet orange. However, casual chatting with colleagues, family members and friends show that lots of people in the population are unsure of the differential nutrient values. Hence it is pertinent to compare the differences between sampled species of citrus fruits that are commonly eaten.
In a critical review of data, there are evidence to show that orange is relatively good on zinc but has least for vitamin $\mathrm{E}$; while lime is best when the cumulative trios of antioxidant copper, vitamin $\mathrm{E}$ and zinc are considered (Figure 3). ${ }^{14}$ The reverse is the case with regards to vitamin $\mathrm{C}$ and folic acid contents. That is, orange is best while lime contains least for vitamin $\mathrm{C}$ and folic acids (Figure 4). These disparities constitute a piece of available knowledge that has yet to be advanced to the general public. Further, it is known that citrus fruits contain lots of vitamin C. What is unknown to the layman in the general population includes that fact that given equal amounts of lime and orange, the former is a better source of antioxidant metal minerals but least in the vitamin $\mathrm{C}$.

Table 4: Comparison of mineral contents* of lemon, lime and orange.

\begin{tabular}{|llllllll|}
\hline Database Ref* & 9150 & 9152 & 9159 & 9160 & 9205 & 9206 \\
\multirow{2}{*}{ Fruit } & Lemon & & Lime & & Orange & Juice \\
\cline { 2 - 7 } & Whole & Juice & Whole & Juice & Whole & 11 \\
\hline Calcium (mg) & 26 & 6 & 33 & 14 & 70 & 0.2 \\
\hline Iron (mg) & 0.6 & 0.08 & 0.6 & 0.09 & 0.8 & 11 \\
\hline Magnesium (mg) & 8 & 6 & 6 & 8 & 14 & 17 \\
\hline Phosphorus (mg) & 16 & 8 & 18 & 14 & 22 & 200 \\
\hline Potassium (mg) & 138 & 103 & 102 & 117 & 196 & 1 \\
\hline Sodium (mg) & 2 & 1 & 2 & 2 & 2 & 1 \\
\hline
\end{tabular}

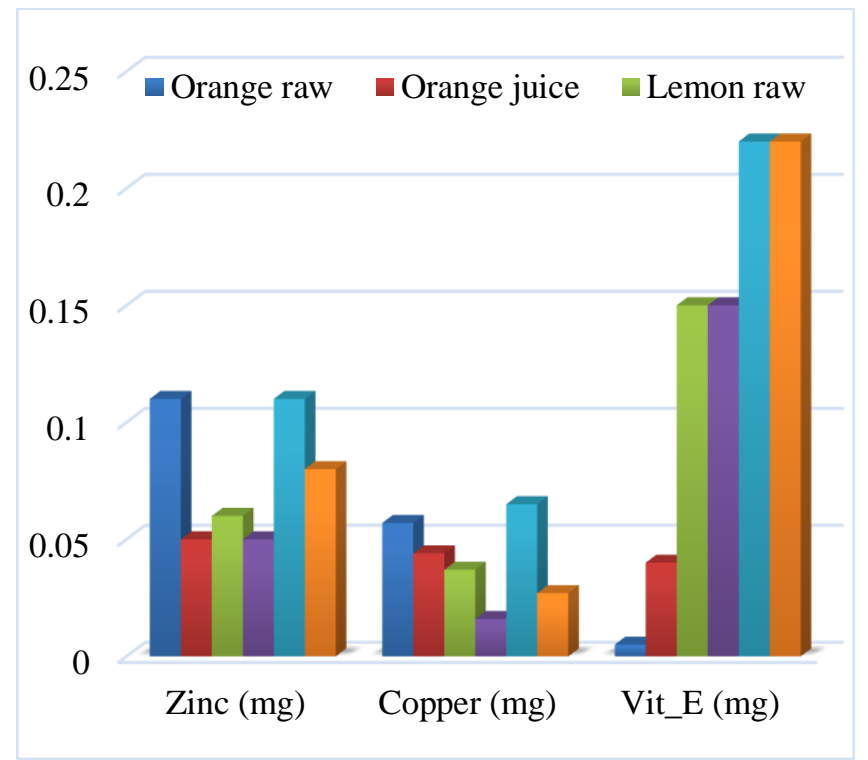

Figure 3: Comparison of antioxidant minerals and vitamin $E$ contents of lemon, lime and orange. ${ }^{14}$

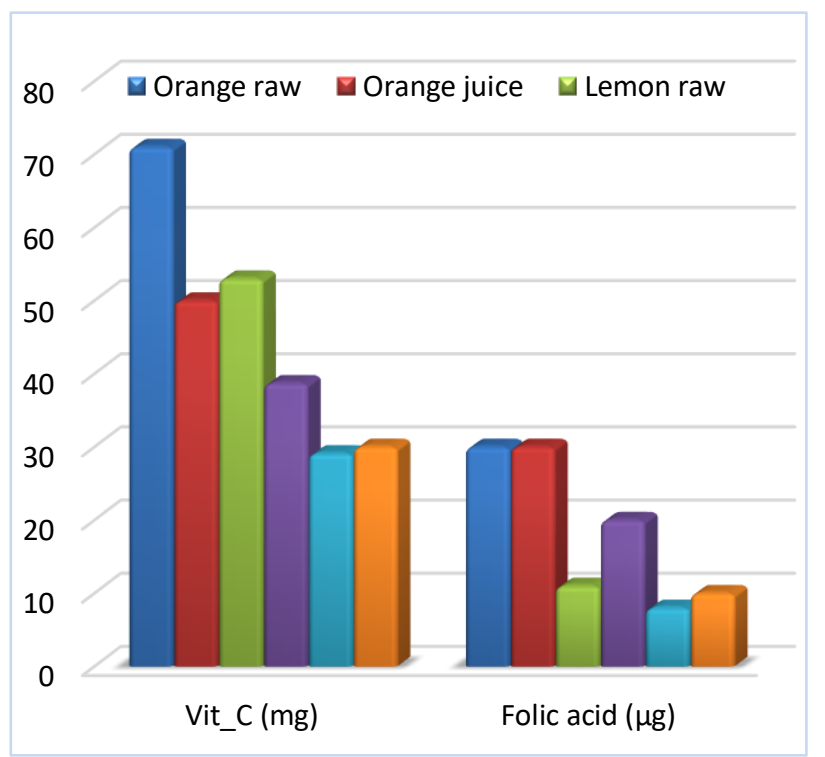

Figure 4: Comparison of vitamin $\mathrm{C}$ and folic acid contents of lemon, lime and orange. ${ }^{14}$ 


\section{COMPARISON OF AVOCADO WITH GUAVA, CUCUMBER, PINEAPPLE, MANGO AND WATERMELON}

\section{Overview}

These are fruits that are commonly eaten raw in Nigeria. Guava and mango are grown albeit not commercially but those who grow them do sell. Commercial pineapple farming is becoming a thing of interest, while cucumber and watermelon are more commonly cultivated in the north and imported to the south where the cultivation is less.

\section{Nutritional values}

It is generally believed that banana is an energy snack. Indeed, the sugar content of banana is higher than that of avocado (Table 5). What is unknown among the general population, which this review highlight is that avocado give more calories than its equivalence of banana (Figure 5). Although molecular biology perspective of nutrition is outside the scope of this work, suffice to note that avocado contains over $\mathrm{x} 44$ of lipids content of banana and this contributes to the calorie difference that overshadows the reverse in carbohydrate gap (Table 5 and Figure 5).

Another point worth mentioning is the differences in fibre content. The fibrous nature of pineapple does not seem to mean higher dietary fibres compared to the other fruits. Apart from cucumber and watermelon, pineapple appears to have the less amount of dietary fibre than mango, guava and avocado (Table 5). In terms of medical nutrition therapeutic value, ${ }^{19}$ however, this low of fibre does not translate to aiding greater calorie vis-à-vis glycaemic index (Figure 5); because of the fat/fibre ratio.

Table 5: Comparison of proximate contents* of fruits.

\begin{tabular}{|lllllllll|}
\hline Ref no. & Fruit & Water & Protein & Lipid total & Ash & Carb' & Fibre & Sugar \\
\hline $\mathbf{0 9 0 3 7}$ & Avocado & 73.23 & 2 & 14.66 & 1.58 & 8.53 & 6.7 & 0.66 \\
\hline $\mathbf{0 9 1 7 6}$ & Mango & 83.46 & 0.82 & 0.38 & 0.36 & 14.98 & 1.6 & 13.66 \\
\hline $\mathbf{0 9 1 3 9}$ & Guava & 80.8 & 2.55 & 0.95 & 1.39 & 14.32 & 5.4 & 8.92 \\
\hline $\mathbf{1 1 2 0 6}$ & Cucumber & 96.73 & 0.59 & 0.16 & 0.36 & 2.16 & 0.7 & 1.38 \\
\hline $\mathbf{0 9 3 2 6}$ & Watermelon & 91.45 & 0.61 & 0.15 & 0.25 & 7.55 & 0.4 & 6.2 \\
\hline $\mathbf{0 9 2 6 6}$ & Pineapple & 86 & 0.54 & 0.12 & 0.22 & 13.12 & 1.4 & 9.85 \\
\hline $\mathbf{0 9 0 4 0}$ & Banana & 74.91 & 1.09 & 0.33 & 0.82 & 22.84 & 2.6 & 12.23 \\
\hline
\end{tabular}

*All values in grams, except where specified; all fruits are raw; carb: carbohydrate $^{14}$

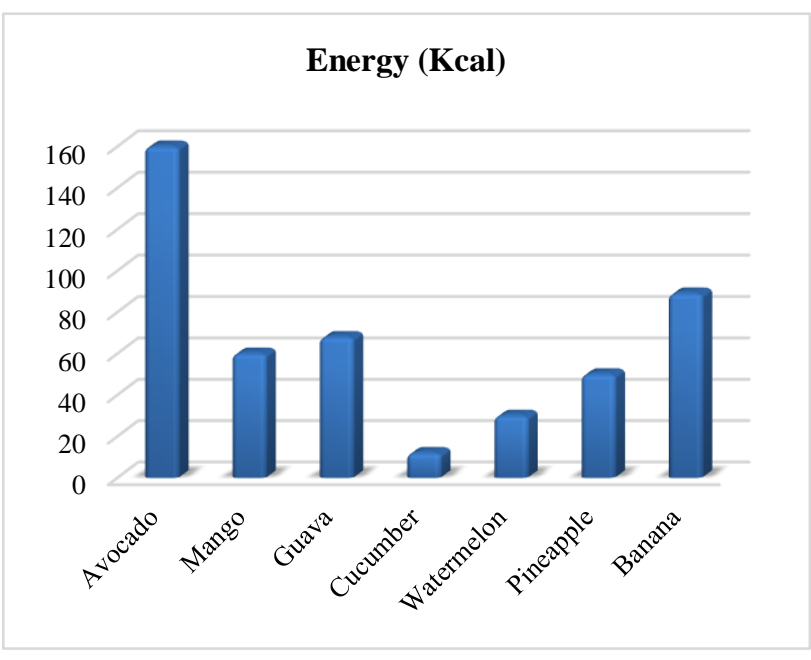

Figure 5: Graphical comparision of energy values among fruits. ${ }^{14}$

\section{Medicinal values}

With particular reference to antioxidant vitamins A, C and E being important in healthy dietary habit, these fruits have varying significance. Table 6 shows that: Vitamin A is highest in mango followed sequentially by guava, watermelon and and avocado. Guava have much higher on vitamin C $(250 \%)$ than orange. Others are less than half $(50 \%)$ the content of orange. Avocado is richest in vitamin $\mathrm{E}$, although not up to recommended daily amount. Other fruits have very low levels of vitamin $\mathrm{E}$ comparable to trace minerals. In addition to vitamin $\mathrm{E}$, avocado seems best when antioxidant minerals copper and zinc are cumulatively considered.

One theme of interest coming from this comparison is lack of any particular nutrient being highest in watermelon to justify the importation of the fruit.

This significance of this observation is in both health behaviour and health economics of a people. ${ }^{20-22}$ It is common knowledge that medical doctors consider affordability of medicines in prescribing treatment. Economists also talk about the concept of affordances, while finance and nutrition are determinants of health. Therefore, educational health promotion advancing the goodness of indigenously available fruits will be helpful in promoting affordable dietary options for healthy living. 
Table 6: Comparative mineral contents of the fruits of interest. ${ }^{14}$

\begin{tabular}{|lllllllll|}
\hline Fruits & Avocado & Mango & Guava & Cucumber & Watermelon & Pineapple & Banana \\
\hline Calcium (mg) & 12 & 11 & 18 & 14 & 7 & 13 & 5 \\
\hline Iron (mg) & 0.55 & 0.16 & 0.26 & 0.22 & 0.24 & 0.29 & 0.26 \\
\hline Magnesium (mg) & 29 & 10 & 22 & 12 & 10 & 12 & 27 \\
\hline Phosphorus (mg) & 52 & 14 & 40 & 21 & 11 & 8 & 22 \\
\hline Potassium (mg) & 485 & 168 & 417 & 136 & 112 & 109 & 358 \\
\hline Sodium (mg) & 7 & 1 & 2 & 2 & 4.1 & 5.5 & 1 \\
\hline Choline total (mg) & 14.2 & 7.6 & 7.6 & 5.7 & 569 & 58 & 9.8 \\
\hline Vit A (IU) & 146 & 1082 & 624 & 72 & 8.1 & 47.8 & 8.7 \\
\hline Vit C (mg) & 10 & 36.4 & 228.3 & 3.2 & 0.05 & 0.02 & 0.10 \\
\hline Vit E (mg) & 2.07 & 0.90 & 0.73 & 0.03 & & & \\
\hline
\end{tabular}

\section{CONCLUSION}

This critical review has utilized an internationally known database to articulate comparative values of fruits that are available in Nigerian markets. Although, some of these values are known by some nutritionists and public health practitioners, much is unknown by the general population hence the indigenous fruits are neither dutifully cultivated nor purposively consumed. It is hoped that this articulation would support effort in health education to promote consumption of fruits in view of healthy dietary habits.

\section{ACKNOWLEDGEMENTS}

Author would like to thanks Isaac Ishiekwene and Taiwo Esther Dada for support this work in different ways and are hereby appreciated. This work as done as part of master of public health project.

\section{Funding: No funding sources Conflict of interest: None declared \\ Ethical approval: Not required}

\section{REFERENCES}

1. Cemansky R. Africa's indigenous fruit trees: A blessing in decline. Environ Health Perspect. 2015;123:A291-6.

2. Nnamani CV, Ajayi SA, Oselebe HO. Sphenostylis stenocarpa (ex. A. Rich.) Harms., a fading genetic resource in a changing climate: Prerequisite for conservation and sustainability. Plants (Basel). 2017;6.

3. Aremu AO, Ncama K, Omotayo AO. Ethnobotanical uses, biological activities and chemical properties of Kei-apple An indigenous fruit tree of southern Africa. J Ethnopharmacol. 2019;241:111963.

4. Mathew NS, Negi PS. Traditional uses, phytochemistry and pharmacology of wild banana (Musa acuminata Colla): A review. J Ethnopharmacol. 2017;196:124-40.

5. Van Andel T, Myren B, Van Onselen S. Ghana's herbal market. J Ethnopharmacol. 2012;140:368-78.

6. Gupta SK, Singhal P, Singh A. Nutritional and pharmaceutical benefits of avocado plants. J Adv Scient Res. 2018;9(2):04-11.
7. Yasir M, Das S and Kharya MD. The phytochemical and pharmacological profile of Persea americana Mill. Pharmacogn Rev. 2010;4:77-84.

8. Dreher ML, Davenport AJ. Hass avocado composition and potential health effects. Crit Rev Food Sci Nutr. 2013;53:738-50.

9. Bahru TB, Tadele ZH, Ajebe EG. A Review on avocado seed: Functionality, composition, antioxidant and antimicrobial properties. Chemical Sci Int J. 2019;27:1-10.

10. Etebu E, Nwauzoma A, Norte A. A review on sweet orange (Citrus sinensis L Osbeck): health, diseases and management. Am J Res Comm. 2014;2:33-70.

11. Alahira J. Orange production. 2020. Avaialble at: https://www.agriculturenigeria.com/manuals/product ion/orange-production/. Accessed on $19^{\text {th }}$ Jan, 2021).

12. Shahbandeh $M$. Orange production worldwide from 2012/2013 to 2019/2020, Available at: https://www.statista.com/statistics/577398/worldorange-production/. Accessed $19^{\text {th }}$ Jan 2021.

13. Knoema. Nigeria-Citrus fruit production quantity, $2018 . \quad$ Avaiable at: https://knoema.com/atlas/Nigeria/topics/Agriculture/ Crops-Production-Quantity-tonnes/Citrus-fruitproduction. Accessed $19^{\text {th }}$ Jan, 2021.

14. US Department of Agriculture and Agricultural Research Service. Nutrient data laboratory. USDA national nutrient database for standard reference, release 28 (Slightly revised) 2016.

15. Favela-Hernández JM, González-Santiago O, Ramírez-Cabrera MA. Chemistry and pharmacology of Citrus sinensis. Molecules. 2016;21:247.

16. Narang N, Jiraungkoorskul W. Anticancer activity of key lime, Citrus aurantifolia. Pharmacogn Rev. 2016;10:118-22.

17. Enejoh OS, Ogunyemi IO, Bala MS. Ethnomedical importance of Citrus aurantifolia (christm) swingle. Pharma Innovation. 2015;4:1-6.

18. Berhow MA, Bennett RD, Poling SM. Acylated flavonoids in callus cultures of Citrus aurantifolia. Phytochemistry. 1994;36:1225-27.

19. Onodu BC, Culas RJ, Nwose EU. Facts about dietary fibre in cassava: Implication for diabetes' medical nutrition therapy. Integr Food Nutr Metab. 2018;5:15 . 
20. Dudley DA, Cotton WG and Peralta LR. Teaching approaches and strategies that promote healthy eating in primary school children: a systematic review and meta-analysis. Int $\mathrm{j}$ behavioral nutri physical activity. 2015;12:28.

21. Shai KN, Ncama K, Ndhlovu PT. An exploratory study on the diverse uses and benefits of locallysourced fruit species in three villages of Mpumalanga Province, South Africa. Foods. 2020;9:1581.

22. Omotayo AO, Ijatuyi EJ, Ogunniyi AI. Exploring the resource value of Transvaal red milk wood
(Mimusops zeyheri) for food security and sustainability: An appraisal of existing evidence. Plants (Basel). 2020;9.

Cite this article as: Osunu PT, Nwose EU. Advancing indigenous fruits consumption to promote self-management in ill-health: a critical narrative review. Int J Basic Clin Pharmacol 2021;10:738-44. 